\title{
Body Area Networking Standardization: Present and Future Directions
}

\author{
Carlos Cordeiro \\ Philips Research N.A. \\ 345 Scarborough Road \\ Briarcliff Manor, NY 10510 \\ carlos.cordeiro@philips.com
}

\author{
Maulin Patel \\ Philips Research N.A. \\ 345 Scarborough Road \\ Briarcliff Manor, NY 10510 \\ maulin.patel@philips.com
}

\begin{abstract}
Body Area Networks (BAN) designed for medical, lifestyle and entertainment applications have drawn the attention of many researchers and industry players alike. This is primarily due to the surge in the number of personal electronic gadgets, new sensing and monitoring devices for in-body and near-body use, device miniaturization, and technological advances in Wireless Sensor Networking (WSN). BAN enables the convergence of these technologies by providing a single unified solution for connectivity in and around the body towards providing the connected consumer experience.

BAN brings about new set of challenges such as scalability (in terms of data rate, power consumption and number of devices), integration of in and around the body networking, interference mitigation, coexistence, QoS, and ultra-low power protocols and algorithms. Moreover, effects on human body have to be considered and several regulatory requirements have to be met. On the standardization side, the IEEE 802.15 Study Group on BAN (SG-BAN) has recently been formed to lead the initiative of developing a single unifying BAN standard that addresses these challenges.

In this paper we study the applications, functional and technical requirements that are at the center of the first BAN specific standards making process. We compare and contrast these requirements with existing low power low data rate WPAN standard called ZigBee. Our goal is to highlight the core set of requirements and research challenges which must be addressed by a BAN standard for it to become ubiquitous and pervasive technology.
\end{abstract}

\section{Categories and Subject Descriptors}

C.2.1 [Computer-communication Networks]: Network Architecture and Design - Wireless Communication

\section{Keywords}

Body Area Networks, wireless, standard

\section{INTRODUCTION}

Recent advances in Wireless and Micro-Electro-Mechanical

Permission to make digital or hard copies of all or part of this work for personal or classroom use is granted without fee provided that copies are not made or distributed for profit or commercial advantage and that copies bear this notice and the full citation on the first page. To copy otherwise, to republish, to post on servers or to redistribute to lists, requires prior specific permission and/or a fee. BODYNETS 2007, June 11-13, Florence, Italy

Copyright (c) 2007 ICST 978-963-06-2193-9

DOI 10.4108/bodynets.2007.140
Table 1: Functional requirements of BAN Apps

\begin{tabular}{|c|c|c|c|}
\hline Application & Data Rate & Latency & BER \\
\hline $\begin{array}{l}\text { Capsule } \\
\text { Endoscope }\end{array}$ & $1 \mathrm{Mbps}$ & - & $<10^{-10}$ \\
\hline ECG & $\begin{array}{l}192 \text { Kbps (6 Kbps, } \\
32 \text { channels) }\end{array}$ & $<250 \mathrm{~ms}$ & $<10^{-10}$ \\
\hline EEG & $\begin{array}{lr}86.4 \text { Kbps } & (300 \mathrm{~Hz} \\
\text { sample, } & 12 \text {-bit } \\
\text { ADC, } 24 \text { channels })\end{array}$ & $<250 \mathrm{~ms}$ & $<10^{-10}$ \\
\hline EMG & $\begin{array}{ll}1.536 \text { Mbps } & (8 \mathrm{kHz} \\
\text { sample, } & 16 \text {-bit } \\
\text { ADC, } 12 \text { channels })\end{array}$ & $<250 \mathrm{~ms}$ & $<10^{-10}$ \\
\hline $\begin{array}{l}\mathrm{O}_{2}, \quad \mathrm{CO}_{2}, \\
\text { Glu. Monitor }\end{array}$ & $1 \mathrm{Kbps}$ & $<20 m s$ & $<10^{-5}$ \\
\hline $\begin{array}{l}\text { Audio, Video, } \\
\text { Med. Imaging }\end{array}$ & $\begin{array}{l}<10 \text { Mbps (e.g. } \\
\text { SD) }\end{array}$ & $<100 \mathrm{~ms}$ & $<10^{-3}$ \\
\hline Voice & $50-100 \mathrm{Kbps} /$ flow & $<10 \mathrm{~ms}$ & $<10^{-3}$ \\
\hline
\end{tabular}

technologies and the proliferation of electronics gadgets in, on and around human body provide a unique opportunity for building next generation wireless BAN technology targeted at medical and consumer applications. BAN is seen as the key technology that will provide a single unified solution for connectivity in and around the body, and which is intended to support a wide range of medical applications such as wellness monitoring, deep brain stimulation, electronic pills, and implanted drug delivery, as well as lifestyle applications including ambient intelligence (e.g., home, office, car), gaming, entertainment, and consumer electronics.

Despite significant technical advanced in WSN technology, BAN poses unique technical challenges primarily due to diversity of applications and their stringent requirements as can be seen from Table 1. Developing a single unifying BAN standard that addresses these complex set of functional requirements is an important first step toward achieving interoperability and economics of scale. With that in mind, the IEEE 802.15 Study Group on BAN (SG-BAN) has been formed in November 2006 [3].

\section{FUNC. \& TECH. REQUIREMENTS}

Table 1 shows the functional requirements of a few typical BAN applications. Notice the wide variation in data rate, BER and delay tolerance which requires scalable solutions with QoS provisions.

Table 2 identifies core technical requirements that should be addressed by a BAN standard and compares these requirements with existing low power, low data rate wireless sensor network standard called ZigBee [2]. ZigBee defines network, transport and application layers on the top of phys- 
Table 2: BAN Technical Requirements

\begin{tabular}{|c|c|c|}
\hline Characteristic & Technical Requirement & ZigBee/802.15.4 \\
\hline $\begin{array}{l}\text { Supported applica- } \\
\text { tions }\end{array}$ & $\begin{array}{l}\text { Medical, Consumer electronics, Entertainment, Gaming, Inter- } \\
\text { active, Ambient intelligence. }\end{array}$ & $\begin{array}{l}\text { Home, Industrial \& Plant automa- } \\
\text { tion, Lighting, Meter reading. }\end{array}$ \\
\hline Operating space & In, on, or around the body. Up to $3 \mathrm{~m}$. & $10 \mathrm{~m}$ to $100 \mathrm{~m}$. \\
\hline Network size & Modest; $<256$ devices per BAN & Huge; Up to $65 \mathrm{~K}$ devices. \\
\hline Data rate & Scalable from sub Kbps up to $10 \mathrm{Mbps}$ (see Table 1 ). & 20,40 or 250 Kbps. \\
\hline Device duty cycle & $\begin{array}{l}\text { Scalable from } 0.01 \% \text { to } 100 \% \text {. Between } 0.01-1 \% \text { in stand-by } \\
\text { mode \& Up to } 100 \% \text { in fully active mode. }\end{array}$ & $\begin{array}{l}\text { Full function devices } 100 \% \& \text { Re- } \\
\text { duce function devices }<100 \% \text {. }\end{array}$ \\
\hline $\begin{array}{l}\text { Target frequency } \\
\text { bands }\end{array}$ & $\begin{array}{l}\text { Unlicensed and Medical approved bands e.g. MICS, MEDS, } \\
\text { ISM, WMTS. (Consumer Electronics applications confined to } \\
\text { ISM bands.) }\end{array}$ & 868,915 or $2400 \mathrm{MHz}$ \\
\hline Power consumption & $\begin{array}{l}\text { Scalable from } 0.01 \mathrm{~mW} \text { to } 40 \mathrm{~mW} \text {. Between } 0.01-1 \mathrm{~mW} \text { in stand- } \\
\text { by mode and Up to } 40 \mathrm{~mW} \text { in fully active mode. }\end{array}$ & $\begin{array}{l}\text { Tx } 25-35 \mathrm{~mW} ; \mathrm{Rx} 25-40 \mathrm{~mW} \text { in } \\
2.4 \mathrm{GHz} \text { band. }\end{array}$ \\
\hline Radiated power & $\begin{array}{l}\text { Meet local regulatory requirements. E.g. SAR (RF energy ab- } \\
\text { sorbed into human tissue) limit imposed in US by the FCC } \\
\text { is } 1.6 \mathrm{~W} / \mathrm{kg} \text { averaged over } 1 \mathrm{~g} \text { of tissue for the General Popu- } \\
\text { lation }[1] \text {. Canada and Australia use this limit as well. The SAR } \\
\text { standard adopted by the European Union is } 2 \mathrm{~W} / \mathrm{kg} \text { averaged } \\
\text { over } 10 \mathrm{~g} \text { of tissue for the General Population [4]. }\end{array}$ & $\begin{array}{llll}1-100 \mathrm{~mW} & \text { (Europe) } & \text { and } & 1 \mathrm{~W} \\
\text { (USA). } & & & \end{array}$ \\
\hline Coexistence & $\begin{array}{l}\text { Coexistence with legacy devices such as WLAN, WPAN, Blue- } \\
\text { tooth and Self-coexistence. Simultaneous collocated operation } \\
\text { of up to } 256 \text { devices belonging to different BANs. }\end{array}$ & $\begin{array}{l}\text { Supports multiple collocated Zig- } \\
\text { Bee devices belonging to different } \\
\text { PAN. }\end{array}$ \\
\hline QoS support & BER: from $10^{-10}$ to $10^{-3}$, Latency: from $10 \mathrm{~ms}-250 \mathrm{~ms}$ & None \\
\hline QoS differentiation & $\begin{array}{l}\text { Hard Real-time, Soft Real-time, Guaranteed delivery, Battery } \\
\text { saving mode, Acks, In order delivery, Asymmetric links. }\end{array}$ & Acks, Best effort. \\
\hline Security & $\begin{array}{l}\text { Privacy, Encryption, Authentication, Message Integrity. MAC, } \\
\text { Network and Application security. }\end{array}$ & $\begin{array}{l}\text { AES } 128 \text { bit encryption, MAC, } \\
\text { Network and App. security. }\end{array}$ \\
\hline Safety, Bio-friendly & Meet regulation requirements for SAR and HIPPA. & Outside the scope of standard. \\
\hline $\begin{array}{l}\text { Location informa- } \\
\text { tion }\end{array}$ & $\begin{array}{l}\text { Localization within a radius of } 10 \mathrm{~cm} \text { for } 67 \% \text { of the cases and } \\
\text { within } 30 \mathrm{~cm} \text { for } 95 \% \text { of the cases. }\end{array}$ & Outside the scope of standard. \\
\hline MAC & Scalable, robust, reliable, low-complexity MAC. & CSMA-CA, Best effort service. \\
\hline Routing & $\begin{array}{l}\text { Simple; Wearable devices: direct communication. Implanted } \\
\text { devices: indirect communication via a wearable device. }\end{array}$ & $\begin{array}{l}\text { Multi-hop, Tree: simple, Mesh: } \\
\text { complex. }\end{array}$ \\
\hline $\begin{array}{l}\text { Robustness, Fault } \\
\text { tolerance }\end{array}$ & $\begin{array}{l}\text { Ability to isolate failures (Node, } \mathrm{H} / \mathrm{W}, \mathrm{S} / \mathrm{W} \text { ) and to recover } \\
\text { from failures. Avoid single point of failure. Zero maintenace. }\end{array}$ & Outside the scope of standard. \\
\hline Synchronization & Synchronize sleep and wake up schedules for energy savings. & Only leaf nodes can sleep. \\
\hline $\begin{array}{l}\text { Ergonomic consider- } \\
\text { ation }\end{array}$ & $\begin{array}{l}\text { Non-invasive, Non-obstructive, Small size, weight, form-factor, } \\
\text { Nomadic, Ambient intelligence, Context awareness. }\end{array}$ & Outside the scope of standard. \\
\hline Reprogramming & Ability to reprogram implanted devices wirelessly. & Outside the scope of standard. \\
\hline Remote calibration & Ability to calibrate implanted devices remotely. & Outside the scope of standard. \\
\hline Network setup time & Up to 1 sec. & $50 \mathrm{~ms}$ \\
\hline
\end{tabular}

ical and MAC layers defined by IEEE 802.15.4. The fact that ZigBee does not address majority of core technical requirements of BAN highlights the need for a standard specifically designed for BAN.

\section{RESEARCH CHALLENGES}

As can be seen from the requirements, a number of research challanges have to be addressed in designing a BAN standard. For example, a $400 \mathrm{MHz}$ MICS band PHY is suitable for implanted devices because of a path loss in the order of $100-120 \mathrm{~dB}$. However, $400 \mathrm{MHz}$ band PHY is not suitable for wearable devices because of limited throughput. $2.4 \mathrm{GHz}-$ ISM band PHY is suitable for wearable devices but it will have very limited range if used for implanted devices. In addition, extensive research and thorough insight are required in the areas of ultra-low power protocols and algorithms, coexistence and interference mitigation, cross-layer design, security and privacy, channel models, to name a few, in order to converge on the most suitable approaches for BAN.

\section{CONCLUSION}

BAN is a promising technology which can revolutionize next generation healthcare and entertainment applications. Developing a unifying BAN standard which addresses the core set of BAN requirements is the quintessential step to unleash the full potential of BAN, and is currently under discussion in the IEEE 802.15 SG-BAN.

\section{REFERENCES}

[1] Cellular Telephone Specific Absorption Rate (SAR). http://www.fcc.gov/oet/rfsafety/sar.html.

[2] Zigbee specification. http://www.zigbee.org, Dec. 2006.

[3] A. W. Astrin. IEEE 802.15.BAN closing report for Dallas, TX. http://www.ieee802.org/15/, Nov. 2006.

[4] European Council. Council recommendation of 12 july 1999 on the limitation of exposure of the general public to electromagnetic fields ( $0 \mathrm{hz}$ to $300 \mathrm{ghz})$. Off J. Eur Communication, pages 59-70, 1999. 